\title{
HIGHLY ACTIVE ANTIRETROVIRAL THERAPY AND EMPLOYMENT STATUS IN ACCRA, GHANA
}

\author{
I.W. HOWLEY ${ }^{1}$, M. LARTEY ${ }^{2}$, J. T. MACHAN ${ }^{3}$, E. A. TALBOT ${ }^{4}$, A. OBO-AKWA ${ }^{2}$, T. P. \\ FLANIGAN $^{5}$ AND A. KWARA \\ ${ }^{1}$ Brown Medical School, Box G-A8355, Providence, Rhode Island 02912, United States \\ ${ }^{2}$ Department of Medicine and Therapeutics, University of Ghana Medical School, Accra \\ Ghana ${ }^{3}$ Lifespan - Rhode Island Hospital and Department of Orthopaedics, Warren Alpert Medical School of \\ Brown University, Providence, Rhode Island, United States ${ }^{4}$ Department of Medicine, Dartmouth Medical \\ School, Hanover, New Hampshire, United States ${ }^{5}$ Department of Medicine, The Warren Alpert Medical \\ School of Brown University, Providence, Rhode Island, United States
}

Corresponding Author: Dr. Margaret Lartey

Conflict of Interest: None declared

\section{SUMMARY}

Objectives: This study investigated the immunologic responses and employment history of highly-active antiretroviral therapy (HAART) patients.

Design: We interviewed patients and reviewed medical records to collect demographic, clinical, and employment history while on HAART. Demographic characteristics were tested as predictors of immunological response while on HAART using hierarchical linear models.

Setting: Fevers Unit, Korle-Bu Teaching Hospital, Accra, Ghana

Participants: Subjects comprised a convenience sample of adult HAART patients receiving therapy for at least 9 months. 270 patients were interviewed. 38 were excluded due to inadequate time on HAART or inability to locate all necessary patient information. Intervention: This was an observational study. Main outcome measures: We investigated the change in CD4 cell count and weight since the initiation of therapy, and their ability to maintain or regain employment as well as the reasons for this. Results: The estimated mean \pm standard error increase in CD4 cell count from baseline at 6, 12, and 18 months were $102 \pm 5,204 \pm 11$, and $236 \pm 10$ cells $/ \mu \mathrm{L}$, respectively. Overall, 147 patients (63.4\%) reported remaining employed or obtaining new employment while on HAART. Patients who were asymptomatic at initial presentation were more likely to remain employed or returned to work while on HAART than those who were symptomatic $(66.4 \%$ vs. $48.8 \%, \mathrm{P}=$ 0.009). Most patients were employed in the informal sector, which made their economic situation particularly vulnerable to HIV-associated illness.

Conclusion: The findings suggest that patients receiving HAART experience good clinical and immunological responses as well as improvement in employment status.
Email: malart38@yahoo.com

Keywords: Highly active antiretroviral therapy, employment, HIV, socioeconomic factors, Ghana

\section{INTRODUCTION}

The human immunodeficiency virus (HIV) epidemic continues to be a major public health problem, particularly in sub-Saharan Africa where $67 \%$ of infected people live and where $75 \%$ of AIDS deaths occurred in 2007. ${ }^{1}$ HIV disease presents both social and economic challenges for patients, families, and employers. HIVrelated stigma, disability, and death can have profound effects on household income, ${ }^{2-5}$ making patients unable to work or forcing them to work less. Sub-Saharan Africa has long been plagued by underdevelopment; the negative effects of HIV illness thus often occur in a setting of pre-existing illness and poverty. ${ }^{6}$

Several studies have demonstrated significant immunologic recover and suppression of viral replication with highly active antiretroviral therapy (HAART). ${ }^{7-10}$ Highly active antiretroviral therapy (HAART) has been associated with increased probability of remaining employed for people living with HIV/AIDS (PLWHA) in industrialized countries, ${ }^{11,12}$ and a prospective study in India also found a significant increase in employment over patients' initial 10 months of therapy. ${ }^{13}$

However, little information exists in the English language literature about the interplay of HAART and employment in sub-Saharan Africa. Studies from other settings cannot be extrapolated to African settings because of regional and social differences in the demographics of AIDS. We hypothesized that improvement in physical well being due to HAART would allow $\mathrm{HIV}$-infected persons to obtain and/or remain in employment. In Ghana, antiretroviral therapy is provided through a government-sponsored program. Patients pay a subsidized monthly fee of 5 Ghana Cedis for counselling, doctor's visit and antiretroviral medication. 
HAART is initiated for HIV patients if they have AIDS-related symptoms, CD4+ counts $<250$ cells $/ \mathrm{mm}^{3}$, or opportunistic infections according to WHO treatment guidelines. Patients are seen at least every 4 months for clinical assessment, adherence monitoring, CD4 count measurements, and counselling when necessary.

HIV viral loads are not performed as a part of routine care. As of August 2007, over 9100 patients had been enrolled in the treatment program. In this study, we characterized the clinical response to HAART and investigated the factors associated with employment for patients who had received at least nine months of therapy at the Korle-Bu Teaching Hospital in Accra.

\section{METHODS}

\section{Study design}

Clinical changes and employment status were investigated in patients on HAART by performing a crosssectional survey and retrospective review of medical records of HIV-infected patients receiving HAART at the Fevers Unit, Korle-Bu Teaching Hospital in Accra, Ghana, as part of the national AIDS treatment program. The study was reviewed and approved by the Institutional Review Boards of the University of Ghana Medical School, Accra and Brown University, Providence, Rhode Island. Written consent was obtained from each patient prior to commencement of the interview.

\section{Study patients and study procedures}

A questionnaire with both open- and closed-ended questions was developed to assess patients' social and demographic characteristics, disclosure of status, and employment history. It was piloted in focus groups comprised of nurses and clerical workers at Korle-Bu Teaching Hospital to improve its contextual appropriateness.

The study was conducted during a seven-week period from June until August July of 2007. Several hundred patients attend each thrice-weekly clinic; patient selection was performed by clinic staff who were asked to choose eligible patients at random from those attending that day's clinic for follow-up routine HIV care. Eligibility criteria were that patients were at least 18 years old and had been on HAART for at least 12 months. A single interviewer performed all interviews.

They were conducted in English with subjects who were fluent in English or, more frequently, in Twi or Ewe using bilingual clinic staff as translators. The questionnaire took approximately 12 minutes to complete. A total of 270 patients were interviewed according to this protocol. Following the interviews, subjects' medical records were reviewed for demographic, clinical, and laboratory data, including World Health Organization (WHO) clinical stage. ${ }^{14}$ Of the patients who had completed the interview, those whose medical records were available were subsequently included in the study.

\section{Statistical analysis}

Analyses were performed using SAS version 9.1.3 (Cary, NC). Each demographic and clinical feature was tested as a predictor of immunological response while on HAART, as demonstrated by changes in CD4 counts. The number and timing of CD4 counts was variable between patients, as well as the length of follow-up and overall CD4 level. Therefore, hierarchical modeling was used to model these changes, allowing each patient to have their own best-fit function over time at the $1^{\text {st }}$ level, and the aggregated function across patients at the $2^{\text {nd }}$ level for testing hypotheses. This method both allows for variable times of measurement and would produce unbiased estimates when missing data was missing at random. Different slopes were modelled in the first year than in subsequent years to allow for patients' expected decreasing response to HAART. This model included both fixed and random intercepts, slopes, and changes in slope at 12 months, with an unstructured variance-covariance structure for the random effect parameters. Follow-up models were used to test whether or not baseline factors moderated the $1^{\text {st }}$ year and subsequent slopes by including interactions of the baseline factor with the slope and change in slope after 1 year. The factors themselves were also included as fixed effects in these models, permitting testing and adjusting for disparate starting points.

Demographic and clinical features were tested for differences by employment status using chi-square or Fisher's exact tests for categorical variables and Student's t-tests for continuous variables. All statistical tests were two-sided, and comparisons at $p<0.05$ were considered significant.

\section{RESULTS \\ Study population}

Of the 270 subjects who were interviewed, 232 (86\%) were included in the final analyses. The difference consisted mostly of patients whose medical charts could not be found at the clinic following their medical appointments. Additionally, chart review revealed a handful of patients to have been on HAART for less than 12 months. Patients who had received at least 9 months of treatment were included in the analyses. The baseline demographic characteristics of the study population are shown in Table 1. 
Table 1 Baseline characteristics of the study subjects

\begin{tabular}{|c|c|c|}
\hline Variable & Number & $\%$ \\
\hline $\begin{array}{l}\text { Age }(\text { Years })(\mathrm{n}=231) \\
\text { Mean (SD) } \\
\text { Range }\end{array}$ & $\begin{array}{l}39.0 \\
19-67\end{array}$ & $(9.0)$ \\
\hline $\begin{array}{l}\text { Age distribution }(\mathrm{n}=231) \\
19-29 \\
30-39 \\
40-49 \\
\geq 50\end{array}$ & $\begin{array}{l}48 \\
77 \\
74 \\
32 \\
\end{array}$ & $\begin{array}{l}20.8 \\
33.3 \\
32.0 \\
13.9 \\
\end{array}$ \\
\hline Female gender & 162 & 70.0 \\
\hline $\begin{array}{l}\text { Marital status } \\
\text { Married } \\
\text { Single } \\
\text { Widowed } \\
\text { Divorced } \\
\text { Separated } \\
\text { Cohabiting } \\
\text { Unknown }\end{array}$ & $\begin{array}{l}103 \\
53 \\
38 \\
27 \\
8 \\
2 \\
1\end{array}$ & $\begin{array}{l}44.4 \\
22.8 \\
16.4 \\
11.6 \\
3.4 \\
0.9 \\
0.4\end{array}$ \\
\hline $\begin{array}{l}\text { Education } \\
\text { University } \\
\text { Secondary/Technical } \\
\text { Junior secondary } \\
\text { Primary } \\
\text { None } \\
\text { Unknown }\end{array}$ & $\begin{array}{l}13 \\
51 \\
116 \\
22 \\
23 \\
7\end{array}$ & $\begin{array}{l}5.6 \\
22.0 \\
50.0 \\
9.5 \\
9.9 \\
3.0\end{array}$ \\
\hline $\begin{array}{l}\text { Source of emotional support } \\
(\mathrm{n}=117) \\
\text { Family } \\
\text { Friends } \\
\text { Other }\end{array}$ & $\begin{array}{l}110 \\
6 \\
1\end{array}$ & $\begin{array}{l}94 \\
5.0 \\
1.0\end{array}$ \\
\hline $\begin{array}{l}\text { WHO staging }(\mathrm{n}=207) \\
1 \\
2 \\
3 \\
4\end{array}$ & $\begin{array}{l}12 \\
70 \\
104 \\
21\end{array}$ & $\begin{array}{l}5.8 \\
33.8 \\
50.2 \\
10.1\end{array}$ \\
\hline $\begin{array}{l}\text { Baseline CD4 cell count } \\
(\text { cells } / \mu \mathrm{L}) \\
\text { Mean (SD) } \\
\text { Range }\end{array}$ & $\begin{array}{l}126.9 \\
1-407\end{array}$ & $(89.3)$ \\
\hline $\begin{array}{l}\text { Antiretroviral regimen } \\
\text { ZDV/3TC/EFV } \\
\text { ZDV/3TC/NVP } \\
\text { D4T/3TC/EFV } \\
\text { D4T/3TC/NVP } \\
\text { ZDV/3TC/NFV } \\
\text { D4T/ABC/EFV } \\
\text { Unknown }\end{array}$ & $\begin{array}{l}85 \\
75 \\
34 \\
34 \\
2 \\
1 \\
1\end{array}$ & $\begin{array}{l}36.6 \\
32.3 \\
14.7 \\
14.7 \\
0.9 \\
0.4 \\
0.4\end{array}$ \\
\hline
\end{tabular}

SD, standard deviation; WHO, World Health Organization; ZDV, zidovudine; 3TC, lamivudine; EFV, efavirenz; NVP, nevirapine; D4T, stavudine; NFV, nelfinavir; ABC, abacavir.

The mean ( \pm SD) age was $39 \pm 9$ years, $70 \%$ were female, and $44.4 \%$ were married. Patients had been on HAART for a mean $( \pm$ SD) duration of $27( \pm 9.7)$ months. The most commonly prescribed medication regimens were lamivudine/zidovudine plus nevirapine $(36.6 \%)$ and lamivudine/zidovudine plus efavirenz $(32.3 \%)$.

\section{Clinical and immunological response to HAART}

The mean $( \pm \mathrm{SD})$ baseline CD4 cell count prior to initiating HAART was $127 \pm 89$ cells $/ \mu 1$, and $60.3 \%$ of patients had WHO stage 3 or 4 disease. There was wide variability in baseline levels and changes in CD4 cell count, hemoglobin values, and body weight over time.

Overall, the estimated mean ( \pm standard error (SE)) increases in CD4 cell count from baseline at 6,12 and 18 months were $102 \pm 5,204 \pm 11$, and $236 \pm 10$ cells $/ \mu \mathrm{L}$, respectively. The estimated mean $( \pm \mathrm{SE})$ increases in hemoglobin at 6,12 , and 18 months were $1.0 \pm 0.2,2.1 \pm 0.3$, and $2.2 \pm 0.3 \mathrm{~g} / \mathrm{dL}$, respectively. The estimated mean ( $\pm \mathrm{SE}$ ) increases in body weight at 6,12 , and 18 months were $3.9 \pm 0.3,7.9 \pm 0.6$, and 7.6 \pm 0.6 kilograms, respectively.

The observed mean increases in CD4 cell count, hemoglobin, and body weight in the first year were all statistically significant $(P<0.0001)$, whereas only CD4 cell count continued to increase after the $1^{\text {st }}$ year $(p$ $<0.0001$ ). We also evaluated factors associated with early (within 1 year) and late CD4 cell count and weight changes while on HAART.

Overall, the mean ( \pm SE) increase in CD4 cell count was $17.1 \pm 0.9$ cells $/ \mu \mathrm{L}$ per month in the first year of HAART and $5.3 \pm 0.8$ cells $/ \mu \mathrm{L}$ per month after the first year. Gender was the only factor that was associated with CD4 count change in the first year of HAART. The estimated mean $( \pm$ SE) increase in CD4 cell count was $18.2 \pm 1.6$ cells $/ \mu \mathrm{L}$ among females compared with $14.2 \pm 1.0$ cells $/ \mu \mathrm{L}$ in males in the first year of HAART $(\mathrm{P}=0.035)$. The change in CD4 cell count over time was not influenced by other measured factors (Table 2).

The most commonly held occupations at the time of interview were trader or food vendor (41.8\%), labourer $(15.1 \%)$, seamstress $(10.8 \%)$, and hairdresser $(7.3 \%)$. Of the 212 patients who had ever worked, $70.3 \%$ were self-employed. Of the 226 patients who were working before becoming symptomatic with HIV, $75.7 \%$ reported taking leave from work or losing their job. At the time of their interviews, 147 (63.4\%) of the 232 patients reported that they were working. Of the 171 patients who took leave from work or lost their job after becoming symptomatic, 101 (59\%) resumed work or obtained new employment. Reasons for temporary or permanent loss of employment included physical inability, loss of business capital, and being fired. 
Overall, of the 75 patients who started new employment on HAART, 47 (62.7\%) earned less money than before their illness. Patients who were asymptomatic at the time of HIV diagnosis were more likely to be working than symptomatic patients $(66.4 \%$ versus $48.8 \%$, p
$=0.009)$. Other measured factors such as age, gender, marital status, educational status, baseline CD4 cell count and WHO disease stage were not associated with employment status while on HAART (data not shown in tables).

Table 2 Mean (standard error ) rate of CD4 cell count (cells/ $\mu \mathrm{l}$ ) increase per month in the first year and after one year of antiretroviral therapy, by patient factors.

\begin{tabular}{|c|c|c|c|c|c|}
\hline \multirow[b]{2}{*}{ Variable } & & \multicolumn{2}{|c|}{ Up to 1 year } & \multicolumn{2}{|c|}{ After 1 year } \\
\hline & & $\begin{array}{l}\text { Change } \\
\text { in CD4 }\end{array}$ & $P$ value & $\begin{array}{l}\text { Change } \\
\text { in CD4 }\end{array}$ & $P$ value \\
\hline \multirow[t]{2}{*}{ Gender } & Male & $14.2(1.0)$ & 0.04 & $4.9(1.4)$ & 0.24 \\
\hline & Female & $18.2(1.6)$ & & $5.5(1.0)$ & \\
\hline \multirow[t]{2}{*}{ Marital status } & Single & $18.4(1.2)$ & 0.10 & $4.9(1.1)$ & 0.19 \\
\hline & Married & $15.4(1.3)$ & & $5.6(1.3)$ & \\
\hline \multirow[t]{2}{*}{ Education } & None/primary & $15.4(2.0)$ & 0.33 & $7.3(2.0)$ & 0.21 \\
\hline & $>$ primary & $17.6(1.0)$ & & $4.9(0.9)$ & \\
\hline \multirow[t]{2}{*}{ Alcohol use } & Yes & $15.7(2.3)$ & 0.72 & $4.2(2.3)$ & 0.85 \\
\hline & No & $16.5(0.9)$ & & $5.8(0.9)$ & \\
\hline \multirow[t]{2}{*}{ Currently working } & Yes & $17.5(1.1)$ & 0.49 & $5.4(1.0)$ & 0.82 \\
\hline & No & $16.3(1.5)$ & & $4.8(1.4)$ & \\
\hline \multirow[t]{2}{*}{ Lost job/took leave } & Yes & $17.1(1.0)$ & 0.89 & $4.5(1.0)$ & 0.47 \\
\hline & No & $17.3(1.8)$ & & $7.1(1.6)$ & \\
\hline \multirow[t]{2}{*}{ Disclosure to family } & Yes & $17.4(1.5)$ & 0.76 & $5.2(1.4)$ & 0.80 \\
\hline & No & $16.8(1.1)$ & & $5.3(1.0)$ & \\
\hline \multirow{2}{*}{$\begin{array}{l}\text { Disclosure to } \\
\text { spouse/partner }\end{array}$} & Yes & $17.4(1.1)$ & 0.56 & $4.1(1.1)$ & 0.20 \\
\hline & No & $16.4(1.4)$ & & $6.7(1.3)$ & \\
\hline \multirow[t]{2}{*}{ Disclosure to friend/pastor } & Yes & $17.2(1.0)$ & 0.77 & $5.2(1.0)$ & 0.75 \\
\hline & No & $16.5(2.0)$ & & $5.6(1.8)$ & \\
\hline \multirow[t]{2}{*}{ Disclosure to parent } & Yes & $16.3(1.1)$ & 0.25 & $5.3(1.1)$ & 0.43 \\
\hline & No & $18.5(1.3)$ & & $5.2(1.4)$ & \\
\hline \multirow[t]{2}{*}{ Disclosure to employer } & Yes & $17.2(0.9)$ & 0.34 & $5.3(0.9)$ & 0.55 \\
\hline & No & $12.9(4.4)$ & & $5.3(4.4)$ & \\
\hline
\end{tabular}

The mean change in body weight was not influenced by any measured patient factors (data not shown)

\section{Employment and factors influencing employment while on HAART}

The cross-sectional patient interview responses are summarized in Table 3.

\section{DISCUSSION}

In this study, we surveyed surviving HIV/AIDS patients attending a large urban clinic in Ghana about their employment experiences before and during therapy. A high proportion of patients recalled having lost their employment, at least temporarily, after becoming symptomatic. However, the majority of these patients were able to resume work or obtain new employment after initiating HAART.
While not conclusive owing to a lack of a control sample, our findings suggest that HAART may improve employment status, as would be consistent with findings in other patient populations. ${ }^{11-13}$

There were significant increases in CD4 cell counts, haemoglobin, and body weight while patients were on HAART. The mean increases in CD4 cell counts and body weight were independent of any factors that we measured except gender, where women had a higher rate of increase in CD4 cell count in the first year of therapy. The importance of this difference is not clear from our analysis. The observed increase in CD4 cell count paralleled what other researchers have found in West Africa, ${ }^{10}$ and demonstrates the effectiveness of the Ghanaian treatment program. 
The only factor that was associated with a higher probability of continuing or obtaining new employment during therapy was being asymptomatic at the initiation of HAART. This corroborates similar findings in industrialized countries, ${ }^{15,16}$ and underscores the importance of early HIV diagnosis and treatment.

A majority of the patients in this study worked in the informal sector as petty traders, seamstresses, hairdressers, and manual labourers. Individuals employed in the informal sector generally have no savings or insurance, and thus are particularly vulnerable to economic and personal stresses.

Table 3 Interview responses regarding socioeconomics characteristics for $232 \mathrm{HIV}$-infected patients who had received at least nine months of antiretroviral therapy

\begin{tabular}{|l|l|l|}
\hline Variable & Number & $\mathbf{\%}$ \\
\hline $\begin{array}{l}\text { Duration of ART at the time of in- } \\
\text { terview (months) }\end{array}$ & & \\
\hline Mean (SD) & $27(9.7)$ & \\
\hline Range & $\begin{array}{l}\text { 4.2 } \\
44.1\end{array}$ & \\
\hline Occupation & & \\
\hline Trader or food seller & 97 & 41.8 \\
\hline Labourer & 35 & 15.1 \\
\hline Seamstress & 25 & 10.8 \\
\hline Hairdresser & 17 & 7.3 \\
\hline Driver & 10 & 4.3 \\
\hline Teacher & 6 & 2.6 \\
\hline Clerical & 6 & 2.6 \\
\hline Management & 6 & 2.6 \\
\hline Other & 17 & 7.3 \\
\hline Unemployed & 13 & 5.6 \\
\hline Self-employed (n=212) & 149 & 70.3 \\
\hline Currently Working & 147 & 63.4 \\
\hline Same occupation (n=147) & 91 & 61.9 \\
\hline $\begin{array}{l}\text { Lost job or took leave since diagno- } \\
\text { sis (n=226) }\end{array}$ & 171 & 75.7 \\
\hline Reason for leave/job loss (n=168) & & \\
\hline Physical inability & 108 & 64.3 \\
\hline Lost of capital & 27 & 16.1 \\
\hline Fired & 18 & 10.7 \\
\hline Lost customers & 6 & 3.6 \\
\hline Resigned & 5 & 3.0 \\
\hline Family leave & 4 & 2.4 \\
\hline $\begin{array}{l}\text { Started new job since illness } \\
\text { (n=122) }\end{array}$ & 79 & 64.8 \\
\hline Started new job after ART (n=78) & 55 & 70.5 \\
\hline $\begin{array}{l}\text { Making less money with new job } \\
\text { (n=75) }\end{array}$ & 47 & 62.7 \\
\hline ART, & & \\
\hline
\end{tabular}

ART, antiretroviral therapy; SD, standard deviation, n, number of patients.
Physical disability due to HIV-related illness reduces patients' income and presents additional costs including medical care, funerals, and the care of orphaned children. ${ }^{2-6,17-19}$ HIV infection is particularly disastrous for patients with pre-existing poverty and poor health, an effect that is not entirely negated by HAART. Early diagnosis through routine testing and early initiation of HAART may prevent many of the deleterious economic effects of HIV-related illness. Vocational rehabilitation and access to micro credit may mitigate the impact of AIDS on self-employed patients.

There are several potential limitations to our methods that merit discussion. There were several possible sources of sampling bias. Clinic staff were asked to identify eligible subjects 'at random,' but no formal process ensured the randomness of the sample. Patients who were lost to follow up due to death, deteriorating health, lack of money, or other reasons were not represented in the study. The results may therefore reflect an overly optimistic view of patients on HAART.

Additionally, an in-house questionnaire was developed and used which was not formally validated or checked for reliability. Despite piloting, some questions did not seem to make sense in the cultural context of Ghanaian society. The definition of occupation may also be problematic. Other researchers, working in Ghana, have noted that people engaged in informal enterprises may have several income generating activities at any given time, picking up and dropping them as their situations change. $^{20,21}$ The questionnaire asked patients about changes in their occupation, attempting to gauge how HIV-related illness and HAART affect employment and personal financial stability. However, it may have inadequately assessed part-time informal ventures that may have contributed to patients' income. Although the study did not adequately anticipate patients' economic situations, the interviews elucidated the economic fragility of patients employed in the informal sector.

The data show that, on average, patients receiving HAART increased in CD4 cell count, hemoglobin, and weight. The majority of those patients who had lost work resumed gainful employment after initiating treatment. Patients who were asymptomatic at presentation had better employment rates than those already suffering from HIV-associated illness. Many patients were employed in informal enterprises, and many of these patients were overwhelmed by new economic burdens levelled by their infection. Room remains for earlier diagnosis and for improved social services to mitigate the economic consequences of HIV infection. This may even enhance patients' abilities to pay for expenses associated with medical treatment. 
The benefit of HAART, and the unaddressed needs highlighted in our study population, merit consideration by policy makers when making decisions about antiretroviral treatment programs in sub-Saharan Africa.

\section{REFERENCE}

1. UNAIDS. AIDS Epidemic Update: December 2007: UNAIDS and WHO; 19 November 2007 2007. 9789291736218 .

2. Bachmann MO, Booysen FL. Health and economic impact of HIV/AIDS on South African households: a cohort study. BMC Public Health. Apr 1 2003;3:14.

3. Bachmann MO, Booysen FL. Relationships between HIV/AIDS, income and expenditure over time in deprived South African households. AIDS Care. Oct 2004;16(7):817-826.

4. Bachmann MO, Booysen FL. Economic causes and effects of AIDS in South African households. AIDS. Sep 11 2006;20(14):1861-1867.

5. Chao LW, Pauly M, Szrek H, et al. Poor health kills small business: illness and microenterprises in South Africa. Health Aff (Millwood) Mar-Apr 2007;26(2):474-482.

6. Hosegood V, Preston-Whyte E, Busza J, Moitse S, Timaeus IM. Revealing the full extent of households' experiences of HIV and AIDS in rural South Africa. Soc Sci Med. Sep 2007;65(6):12491259.

7. Calmy A, Pinoges L, Szumilin E, et al. Generic fixed-dose combination antiretroviral treatment in resource-poor settings: multicentric observational cohort. AIDS. May 2006;20 (8):1163-1169.

8. Hammond R, Harry TC. Efficacy of antiretroviral therapy in Africa: effect on immunological and virological outcome measures a meta-analysis. International Journal of STD \& AIDS May 2008;19(5):291-296.

9. Ivers LC, Kendrick D, Doucette K. Efficacy of antiretroviral therapy programs in resource-poor settings: A meta-analysis of the published literature. Clinical Infectious Diseases Jul 2005;41(2):217-224.

10. Laurent C, Kouanfack C, Koulla-Shiro S, et al. Effectiveness and safety of a generic fixed-dose combination of nevirapine, stavudine, and lami- vudine in HIV-1-infected adults in Cameroon: open-label multicentre trial. Lancet. Jul 3-9 2004;364(9428):29-34.

11. Dray-Spira R, Lert F. Living and working with HIV in France in 2003: results from the ANRSEN12-VESPA Study. AIDS. Jan 2007;21 Suppl $1: \mathrm{S} 29-36$.

12. Goldman DP, Bao Y. Effective HIV treatment and the employment of $\mathrm{HIV}(+)$ adults. Health Serv Res Dec 2004;39(6 Pt 1):1691-1712.

13. Ajithkumar $\mathrm{K}$, Iype $\mathrm{T}$, Arun $\mathrm{KJ}$, Ajitha $\mathrm{BK}$, Aveenlal KP, Antony TP. Impact of antiretroviral therapy on vocational rehabilitation. AIDS Care Nov 2007;19(10):1310-1312.

14. World Health Organization. WHO case definitions of HIV for surveillance and revised clinical staging and immunological classification of HIVrelated disease in adults and children. Geneva; 2007.

15. Fogarty AS, Zablotska I, Rawstorne P, Prestage G, Kippax SC. Factors distinguishing employed from unemployed people in the Positive Health Study. AIDS Jan 2007;21 Suppl 1:S37-42.

16. Bernell SL, Shinogle JA. The relationship between HAART use and employment for HIVpositive individuals: an empirical analysis and policy outlook. Health Policy Feb 2005;71(2):255-264.

17. Alkenbrack Batteh SE, Forsythe S, Martin G, Chettra T. Confirming the impact of HIV/AIDS epidemics on household vulnerability in Asia: the case of Cambodia. AIDS Jul 2008;22 Suppl 1:S103-111.

18. Collins DL, Leibbrandt $M$. The financial impact of HIV/AIDS on poor households in South Africa AIDS Nov 2007;21 Suppl 7:S75-81.

19. Mahal A, Canning D, Odumosu K, Okonkwo P. Assessing the economic impact of HIV/AIDS on Nigerian households: a propensity score matching approach. AIDS Jul 2008;22 Suppl 1:S95-101.

20. Hart K. Informal Income Opportunities and Urban Employment in Ghana. The Journal of Modern African Studies 1973;11(1):61-89.

21. Lyons M, Snoxell S. Sustainable urban livelihoods and marketplace social capital: Crisis and strategy in petty trade. Urban Studies Jul 2005;42(8):1301-1320. 